\title{
Spatial and temporal distribution of house infestation by Triatoma infestans in the Toro Toro municipality, Potosi, Bolivia
}

Jorge Espinoza Echeverria ${ }^{1 *}$, Antonio Nogales Rodriguez ${ }^{2}$, Mirko Rojas Cortez ${ }^{3}$, Liléia Gonçalves Diotaiuti ${ }^{1}$ and David E. Gorla ${ }^{4}$

\begin{abstract}
Background: Triatoma infestans is the main vector of Trypanosoma cruzi in Bolivia. The species is present both in domestic and peridomestic structures of rural areas, and in wild ecotopes of the Andean valleys and the Great Chaco. The identification of areas persistently showing low and high house infestation by the vector is important for the management of vector control programs. This study aimed at analyzing the temporal and spatial distribution of house infestation by T. infestans in the Toro Toro municipality (Potosi, Bolivia) between 2009 and 2014, and its association with environmental variables.
\end{abstract}

Methods: House infestation and T. infestans density were calculated from entomological surveys of houses in the study area, using a fixed-time effort sampling technique. The spatial heterogeneity of house infestation was evaluated using the SatScan statistic. Association between house infestation with Bioclim variables (Worldclim database) and altitude was analyzed using a generalized linear model (GLM) with a logit link. Model selection was based on the Akaike information criteria after eliminating collinearity between variables using the variable inflation factor. The final model was used to create a probability map of house infestation for the Toro Toro municipality.

Results: A total of 73 communities and 16,489 house evaluation events were analyzed. Presence of $T$. infestans was recorded on 480 house evaluation events, giving an overall annual infestation of $2.9 \%$ during the studied period (range 1.5-5.4\% in 2009 and 2012). Vector density remained at about 1.25 insects/ house. Infestation was highly aggregated in five clusters, including 11 communities. Relative risk of infestation within these clusters was 1.7-3.9 times the value for the regional average. Four environmental variables were identified as good descriptors of house infestation, explaining $57 \%$ of house infestation variability. The model allowed the estimation of a house infestation surface for the Toro Toro municipality.

Conclusion: This study shows that residual and persistent populations of T. infestans maintain low house infestation, representing a potential risk for the transmission of T. cruzi in these communities, and it is possible to stratify house infestation using $\mathrm{EV}$, and produce a risk map to guide the activities of vector control interventions in the municipality of Toro Toro (Potosi, Bolivia).

Keywords: Triatoma infestans, House infestation, Chagas disease, Environmental variables

\footnotetext{
* Correspondence: jorgeespinozaecheverria@gmail.com

${ }^{1}$ Laboratório de Referência Triatomíneos e Epidemiologia da Doença de

Chagas, Centro de Pesquisas René Rachou, FIOCRUZ- MG, Belo Horizonte,

Brazil

Full list of author information is available at the end of the article
}

(c) The Author(s). 2017 Open Access This article is distributed under the terms of the Creative Commons Attribution 4.0 International License (http://creativecommons.org/licenses/by/4.0/), which permits unrestricted use, distribution, and reproduction in any medium, provided you give appropriate credit to the original author(s) and the source, provide a link to the Creative Commons license, and indicate if changes were made. The Creative Commons Public Domain Dedication waiver (http://creativecommons.org/publicdomain/zero/1.0/) applies to the data made available in this article, unless otherwise stated. 


\section{Background}

Chagas disease remains one of the most important endemic diseases in the Americas [1]. The main mode of transmission in endemic areas is the vectorial route, by domestic, peridomestic, or sylvatic triatomines [2, 3]. At a global scale, an estimated 7 million people are infected by Trypanosoma cruzi [1]. In Latin America, the main vector is Triatoma infestans, a species widely distributed on the continent $[4,5]$, showing high vectorial capacity for the transmission of T. cruzi, because of its close association with man [6] and habitation of domestic and peridomestic structures [7].

The historical endemic area of Chagas disease in Bolivia covers around $60 \%$ of the country and corresponds to six of its nine Departments. Bolivia had one of the highest rates of house infestation by $T$. infestans and people infection by $T$. cruzi in Latin America [8-10]. The vectorial transmission of $T$. cruzi is almost exclusively due to domestic populations of $T$. infestans $[11,12]$, and (in some areas) this species was present in more than $98 \%$ of houses evaluated in rural and periphery-urban areas [13], before the implementation of the National Program of Chagas disease in the 2000's. The Potosi Department, in the south of Bolivia, is considered one of the poorest $(86 \%$ poverty), and has precarious housings that favor the establishment and development of triatomines (a scenario generally described in highly endemic areas of Chagas disease) [14-17]. These features are currently responsible for the persistence of $T$. infestans in 20 of the 40 provinces in the municipality of Toro Toro [18].

Within the first two decades after the initiation of the Southern Cone Initiative (INCOSUR) to control the transmission of T. cruzi by T. infestans, Brazil, Chile, Uruguay and wide areas of Argentina and Paraguay certified the interruption of the vectorial and blood-bank transmission of T. cruzi [19]. However, the success of the constant efforts to control $T$. infestans was limited in the Gran Chaco of Argentina, Bolivia and Paraguay and in some areas of the Inter-Andean Valleys of Bolivia [20, 21].

Traditionally, the control programs focus on the interruption of the vectorial transmission using insecticides with residual action (especially pyrethroids) to spray human dwellings and on the interruption of transfusional transmission of T. cruzi [22]. The main obstacle for a successful vector control intervention is the reinfestation of domestic and peridomestic structures from residual populations, that have either survived the insecticide treatment, or occupied houses that were not treated for some reason or from wild triatomine populations invading domestic premises [23-25]. Vector control failures due to high levels of insecticide resistance were reported mainly on the border between Argentina and Bolivia, in the biogeographical region of the Gran Chaco [26-28].
Identification of areas with persistent house infestation by the vector is very important for the control program management. The description and modelling of vector infestation distribution at the regional level are important inputs to understand the responses of the vector populations to a broad range of environmental conditions. This study aims at analyzing the spatial and temporal variation of house infestation by $T$. infestans in the municipality of Toro Toro (Potosi, Bolivia) during the period 2009-2014, and its association with environmental variables.

\section{Methods}

\section{Study area}

The study was carried out in the municipality of Toro Toro (Charcas Province), north of Potosi Department, Bolivia. It has an area of $1.172 \mathrm{~km}^{2}$, is inhabited by 12,086 people living in 3,511 houses in 73 communities [17]. Biogeographically, the area is part of the provinces of Puna and Bolivian-Tucuman [29], with an altitude ranging from 1,900-3,600 meters above sea level [30].

Farming is the main form of agriculture in Toro Toro, especially potato production and animal husbandry (cattle, goats, sheep and poultry). Of the total population, 97\% are poor and $86 \%$ live in extreme poverty [31]. Housing is frequently precarious $(81 \%)$. Most houses in the municipality are built with adobe, stone, thatched roofs and have dirt floors. Houses in the main town (Toro Toro) are of better quality. The majority of houses in the municipality has some peridomestic structure for the protection of domestic animals (i.e. goat corrals and chicken coops).

\section{House infestation and vector density}

The information on house infestation by $T$. infestans was provided by the National Chagas Program of Bolivia (NPCCD), and Health Departmental Service (SEDES Potosi). Between 2009 and 2014 field teams evaluated house infestation in the municipality on an almost yearly basis. Although coverage was not complete, 16,489 house evaluation events were carried out during the period. A few communities were evaluated twice a year (Additional file 1: Table S1). The temporal analysis included estimates of the yearly house infestation recorded in the 73 communities in the municipality of Toro-Toro.

The annual entomological evaluation was carried out by field teams consisting of two technicians that spent 15 min searching inside houses (intradomicile) and peridomestic structures, completing 1-man-hour search on each house, according to standardized procedures of the Pan American Health Organization [32, 33].

House infestation (per year and for the whole study period) was calculated as the number of houses found to contain T. infestans, divided by the number of houses evaluated during the 2009-2014 period (Additional file 2: 
Table S2). Because houses were evaluated repeatedly during the study period, house infestation estimations might not be independent, and house evaluation within a community not always random. Because of this data feature, we carried out a detailed analysis of data properties (Additional file 3: Table S3), and decided the best option to estimate house infestation was to combine all infested and evaluated houses, by year. After the entomological evaluation, all infested houses were sprayed with alphacypermethrin at a nominal dose of $50 \mathrm{mg}$ active ingredient $/ \mathrm{m}^{2}$, using Hudson X-Pert ${ }^{\mathrm{Tm}}$ manual sprayers. If house infestation at the community level was higher than $5 \%$, all houses in the locality were sprayed, as indicated by the PAHO protocol [34, 35]. Annual house and community coverage was calculated as number of evaluated houses (or communities) divided by the number of houses in the community (or the number of communities in the municipality). Triatoma infestans density was calculated as the number of insects collected during the active search using the man-hour technique, divided by the number of infested houses.

\section{Data analyses}

Data analysis focused on three main aspects of this study: description of house infestation and vector density during the period 2009-2014, detection of spatial heterogeneity of house infestation, and analysis of the association between house infestation and environmental variables.

Annual values of house infestation were calculated and risk of house infestation was compared using odds ratios (OR). Temporal trend in house infestation and vector density was analyzed using a generalized linear model ( $g l m$ package of R 3.3.0) [36] and was compared using the Kruskal-Wallis test.

To analyze the spatial heterogeneity of house infestation, the spatial scan statistic [37], was used to measure possible spatial heterogeneity of house infestation and to detect clusters of significant high house infestation, compared with the regional average. The unit of analysis was the community, the circular shape of the spatial scan was used for cluster detection with a maximum circle size equal to $50 \%$ of the whole area, and the Poisson model was selected. Although data on house infestation were collected during 2009-2014, these were aggregated by community and the analysis was carried out as an atemporal, pure spatial process [38].

The association between house infestation by community and environmental variables was studied using a generalized linear model with a logit link. Environmental variables included the Bioclim set (Bio1 to Bio19) and altitude (i.e. 20 environmental variables) contained in the Worldclim database (http://www.worldclim.org/) [39] at $1 \mathrm{~km}^{2}$ spatial resolution. Bio1 to Bio9 include variables related to temperature, whereas Bio10 to Bio19 include variables related to rainfall.
Collinearity between environmental variables was estimated through the variance inflation factor (vif). Only environmental variables with vif $<10$ (non-linearly related) were used to fit the final model. The model was used to produce a surface of estimated probability of house infestation in the study area using the raster package in $\mathrm{R}$.

\section{Results}

\section{Temporal and spatial analysis of house infestation and insect density}

House evaluation coverage within communities was relatively low, ranging from $30.8 \%$ (2012) to $65.6 \%$ (2013), whereas community coverage was higher, ranging between $45.2 \%$ (2011) and $80.8 \%$ (2009) during the study period (Table 1). A total of 16,489 house evaluation events were carried out over the 73 communities of Toro Toro from 2009 to 2014, giving an overall average of 0.78 house evaluations per house/year. Among these evaluation events, 480 gave positive results for the presence of $T$. infestans, giving an overall house infestation for the municipality of $2.9 \%$ during the studied period. Annual values of house infestation varied between 1.5\% (2009) and 5.4\% (2012) (Fig. 1). Compared with 2009 values, house infestation risk (measured by OR) was between 1.68 and 3.88 times higher in the following years, except in 2011, when infestation risk was similar to 2009 (Table 1).

Vector density varied between 1.1 and 3.2 insects per infested house (2009 and 2012, respectively). Although higher density was observed during 2011 and 2012, vector density remained at about 1.25 insects per infested house. Density in intradomestic structures was about 7 times lower (Kruskal-Wallis test, $\chi^{2}=50.75, d f=1, P<0.0001$ ) than density in peridomestic ones. Of the recorded infested houses, only $10 \%$ (48 out of 480 ) were colonized with nymphs, whereas the other harbored only adults.

House infestation was not homogeneously or randomly distributed in Toro Toro, but showed an aggregated

Table 1 Community coverage (CC), house coverage (HC), number of house evaluations (HE) and house infestation (number of positive houses) by T. infestans in the study area between 2009 and 2014

\begin{tabular}{|c|c|c|c|c|c|c|c|}
\hline \multirow[t]{2}{*}{ Year } & \multirow{2}{*}{$\begin{array}{l}\text { CC } \\
(\%)\end{array}$} & \multirow{2}{*}{$\begin{array}{l}\mathrm{HC} \\
(\%)\end{array}$} & \multirow[t]{2}{*}{$\mathrm{HE}$} & \multirow{2}{*}{$\begin{array}{l}\text { No. of } \\
\text { infested } \\
\text { houses (\%) }\end{array}$} & \multirow[t]{2}{*}{ OR $(95 \% C l)^{a}$} & \multicolumn{2}{|c|}{ Density } \\
\hline & & & & & & ID & PD \\
\hline 2009 & 80.8 & 56.2 & 3,391 & $52(1.5)$ & - & 0.37 & 0.71 \\
\hline 2010 & 65.7 & 37.9 & 2,287 & $90(3.9)$ & $2.63(1.86-3.72)^{*}$ & 0.21 & 0.94 \\
\hline 2011 & 45.2 & 41.6 & 2,510 & $49(1.9)$ & $1.28(0.86-1.89)$ & 0.67 & 2.53 \\
\hline 2012 & 46.5 & 30.8 & 1,858 & $106(5.4)$ & $3.88(2.77-5.44)^{*}$ & 0.24 & 1.56 \\
\hline 2013 & 76.7 & 65.6 & 3,958 & $101(2.5)$ & $1.68(1.19-2.36)^{*}$ & 0.04 & 1.65 \\
\hline 2014 & 57.5 & 41.1 & 2,485 & $82(3.2)$ & $2.19(1.54-3.11)^{*}$ & 0.04 & 1.38 \\
\hline
\end{tabular}

${ }^{*} P<0.05$

aodds ratio, compared with infestation in 2009

Abbreviations: $\mathrm{Cl}$ confinence interval, ID intradomestic, $P D$ peri-domestic 


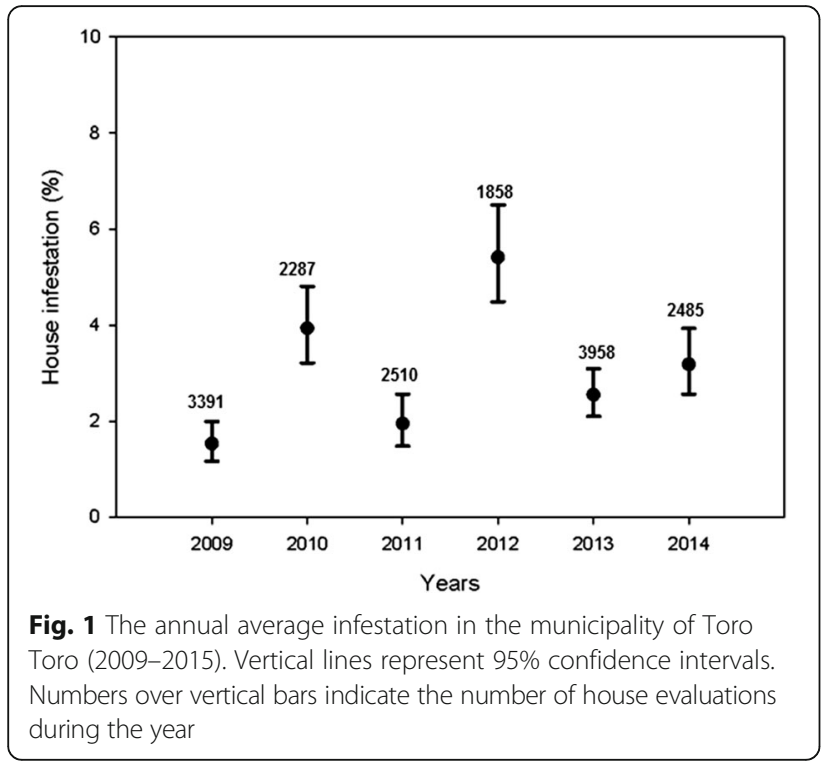

spatial distribution, with five significant community clusters of high house infestation (Fig. 2). These clusters grouped 4,359 of 16,489 house evaluation events from 11 of 73 communities in the municipality and showed values of house infestation between two and three times higher than the average house infestation (Table 2).

\section{House infestation and environmental variables}

Four environmental variables proved to be good descriptors of house infestation in the study area. The glm produced a significant model that explained $57 \%$ of the variation, with an AIC of 391.58 with four environmental variables: mean diurnal temperature range (Bio2), temperature seasonality (Bio4), minimum temperature of
Table 2 High house infestation aggregates (clusters) in the rural communities of the municipality of Toro Toro

\begin{tabular}{llll}
\hline Clusters & Communities & Infestation \% (CP/ CE) & Relative risk \\
\hline 1 & Calahuta; & $7.1(131 / 1,852)$ & 2.9 \\
& Hacienda Loma; & & \\
& Kehuayllani; & & \\
& Sucusuma & & \\
& Omereque; & $8.3(46 / 566)$ & \\
2 & Paloma Pampa & & \\
3 & Julo Chico; & $4.9(82 / 1,650)$ & \\
& Julo Grande; & & \\
4 & Kirusmayu & & 2.7 \\
5 & Aguas Calientes & $7.6(30 / 390)$ & 2.6 \\
\hline
\end{tabular}

Abbreviations: $C E$ number of house evaluations, $C P$ number of infested houses

the coldest month (Bio6) and precipitation of the coldest quarter (Bio19). A second model that only included the minimum temperature of the coldest month was also significant and showed as the second best model describing house infestation explaining 53\% of the variation, with an AIC of 405.4. Although statistically different from the first model, this univariate model showed little difference of AIC and residual deviance values. No house was found infested in communities with temperature of the coldest month below $0{ }^{\circ} \mathrm{C}$. Figure 3 shows the observed dispersion diagram between temperature of the coldest quarter and house infestation, whereas Table 3 reports on parameter estimates for both models. Using the estimated fourvariable model mentioned above, and rasters of the four selected environmental variables, an estimated surface of house infestation was calculated for the municipality

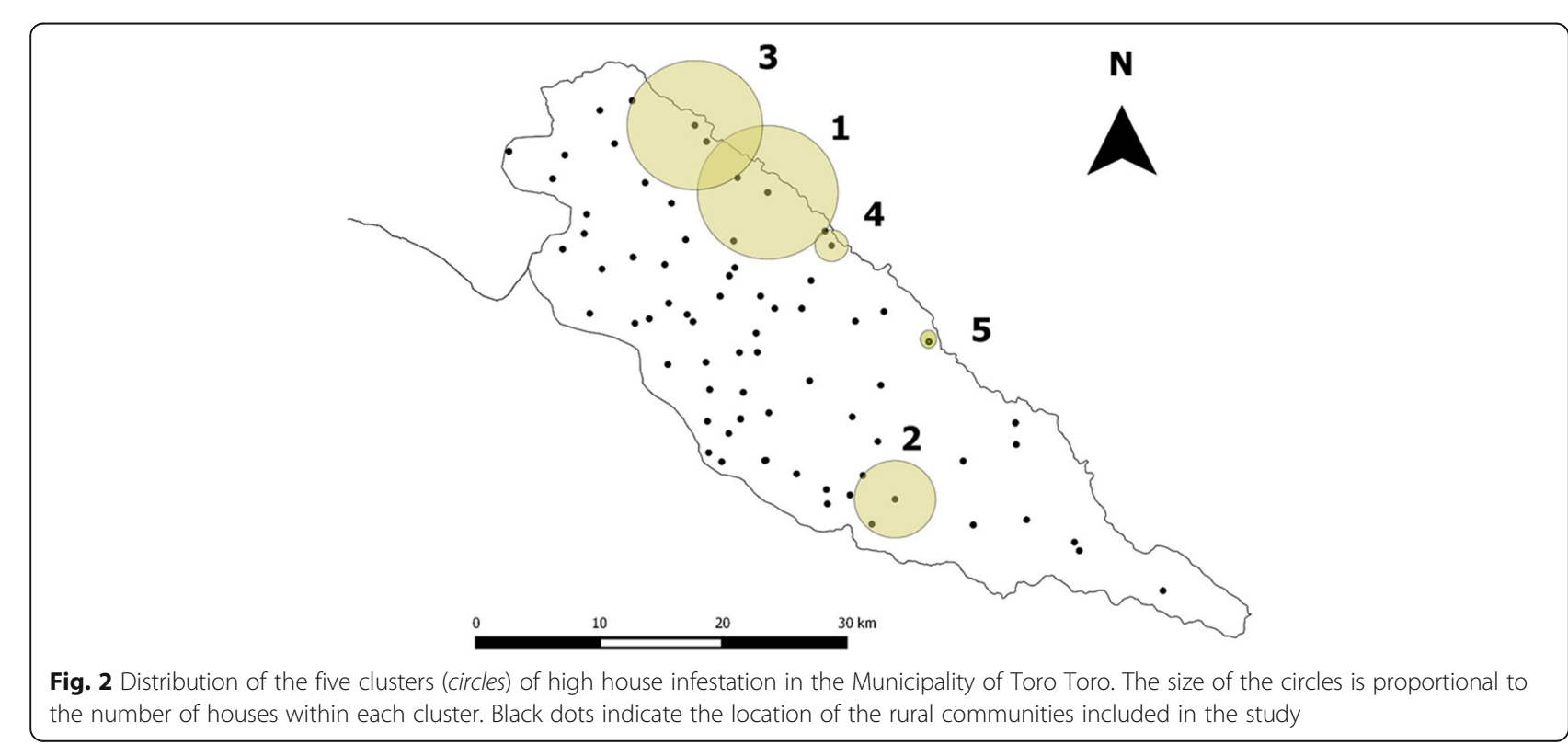




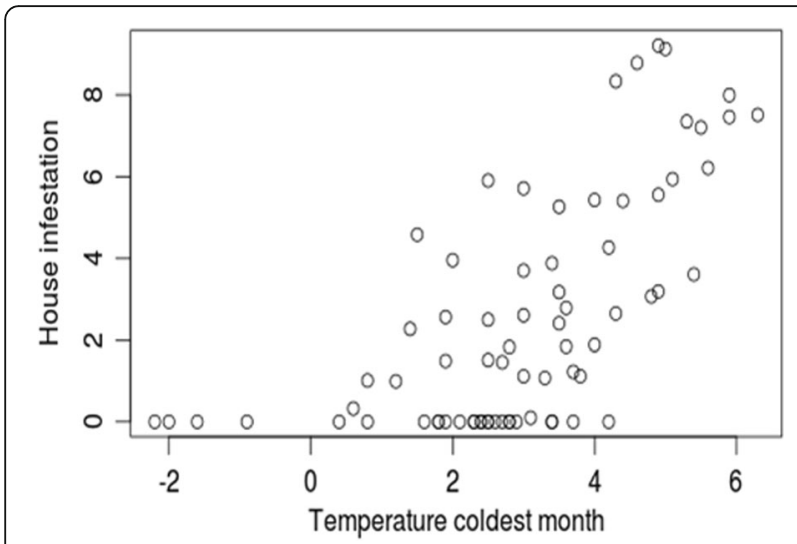

Fig. 3 Dispersion diagram showing the relationship between the temperature $\left({ }^{\circ} \mathrm{C}\right)$ of the coldest month and house infestation (\%) in each rural community studied

(Fig. 4). The estimated surface shows the spatial heterogeneity of house infestation, with higher values in the northern limit of the municipality, and along the southern hillsides and valleys towards the southeast.

\section{Discussion}

Reports on house infestation by triatomines in Bolivia date back to pre-Columbian times [11,40]. Indices reported in rural areas (70-100\%) were higher than those reported in peri-urban areas (40-60\%) [41, 42]. From 2000 onwards, a considerable reduction of house infestation by T. infestans was attained in Bolivia. However, only the Departments of La Paz and Potosi were certified free of vectorial transmission $[1,18]$, although the species persists in reduced population remnants throughout these Departments.

Within highly endemic provinces in the Department of Potosi, the municipality of Toro Toro (Charcas Province) draws attention due to the extreme poverty in the region $[18,31]$ and precarious housing, which generally favor the establishment and development of domestic triatomines. Such a scenario is typical in highly endemic areas $[14,15]$. Before the intervention of the vector control program in

Table 3 Estimated parameters of the generalized linear model for house infestation by $T$. infestans based on four environmental variables $(P<0.05)$. Null deviance: 497 on 72 degrees of freedom; residual deviance: 213.61 on 68 degrees of freedom; AIC: 391.58

\begin{tabular}{|c|c|c|c|c|}
\hline Variable & & Estimate & Standard Error & $\operatorname{Pr}(>|z|)$ \\
\hline Intercept & & -1.88 & 3.57 & 0.59 \\
\hline Bio 2 & $\begin{array}{l}\text { Mean diurnal temperature } \\
\text { range }\end{array}$ & -0.04 & 0.02 & 0.05 \\
\hline Bio 4 & Temperature seasonality & $1.71 e^{-3}$ & $4.0 e^{-3}$ & $1.39 e^{-4}$ \\
\hline Bio 6 & $\begin{array}{l}\text { Minimum temperature of } \\
\text { the coldest month }\end{array}$ & 0.03 & $7.11 e^{-3}$ & $6.86 e^{-5}$ \\
\hline Bio 19 & $\begin{array}{l}\text { Precipitation of the } \\
\text { coldest quarter }\end{array}$ & -0.04 & 0.02 & $7.92 e^{-3}$ \\
\hline
\end{tabular}

2000, the municipalities of the Potosi Department showed house infestation of up to $75 \%$, which can be considered high when compared to current estimations [18].

In this study, we estimated that on average, the domestic infestation between 2009 and 2014, in 73 communities in the municipality of Toro Toro was $2.9 \%$, similar to domestic infestation observed in the neighbor Department of Cochabamba between 2004 and 2011, where after a chemical intervention, the domestic infestation indices were 2$3 \%$ [43]. In other areas, outside the Andean valleys, within the Bolivian Chaco, the household infestation after intervention with insecticides dropped to $1.7 \%$ [44].

Comparing house infestation at the beginning of the study period (2009), the risk was always higher in subsequent years (odds ratios between 1.68 and 3.88), except for 2011. The lowest and highest value of annual infestation in the Toro Toro municipality were observed in 2009 and 2012. This variation could be the result of differences in the number of communities covered by the control program (80.2\% in 2009 and $46.5 \%$ in 2012), and probably because in these communities only 56.2 and $30.8 \%$ of the houses were evaluated each year.

Despite the great effort by the vector control program, it is not always possible to cover all of the communities or houses. Low coverage can be attributed to the difficulties accessing certain communities, the absence of owners at the time of the evaluation, or other high priority endemic diseases draining personnel and/or funding. Beside low coverage, vector control efficacy could also be related to the vectors low susceptibility to pyrethroids. Although variable, house infestation by $T$. infestans in Toro Toro remains low (an overall 2.9\%), but similar to those for houses in the neighbor regions of Potosi and Cochabamba.

It is important to emphasize that house infestation indices in the municipality before the establishment of the vector control program were as high as $80 \%$ [18]. As a consequence, high prevalence rates of Chagas disease were recorded in different age groups of the affected communities [12]. According to our results, house infestation remains low; however, a latent risk of $T$. cruzi transmission remains in these communities due to the persistence of $T$. infestans in both intra- and peridomestic structures. As such, it is important to maintain up-to-date knowledge of vector numbers, the cause(s) of the persistence of the house infestation, and control activities.

The low density of $T$. infestans in domestic environments observed during this study may be due to house construction material(s) $[45,46]$, the size of the dwelling and the number of individuals per room, the presence of domestic animals [47-49] and the use of household insecticides [46]. Higher densities of triatomines observed in the peridomicile may be due to the numerous structures (i.e. goat corrals and chicken coops) that create favorable microclimatic conditions for $T$. infestans $[50,51]$ 


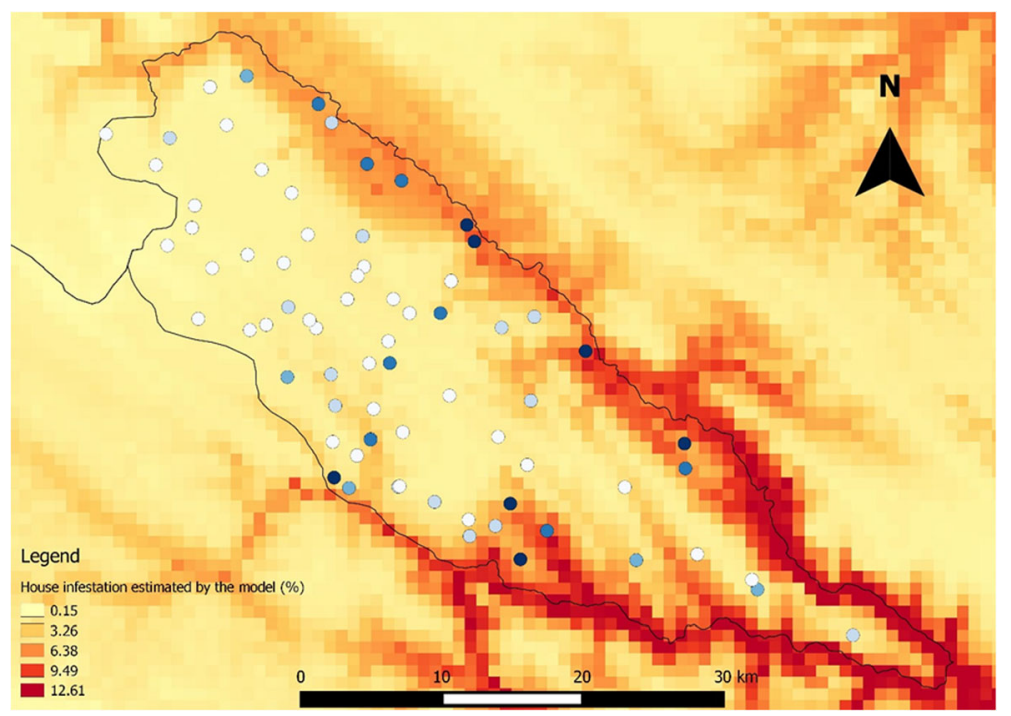

Fig. 4 House infestation values estimated by the model with four Bioclim variables in the municipality of Toro Toro (see text). White to dark blue circles indicate the location of the communities and the observed house infestation throughout the study period (2009-2014), from low (white circles) to high (deep blue circles)

by providing refuges and oviposition sites $[46,48]$, and refuges from insecticides.

The pattern of house infestation within the studied communities was highly clumped, heterogeneously distributed throughout the municipality of Toro Toro. The infestation clusters including 11 communities showed house infestation ranging from 7 to $8 \%$. The spatial analysis of house infestation by T. infestans, as shown here, helps in the stratification of risk in rural communities of endemic areas. The identification of risk factors and spatial heterogeneity over wide geographical areas [52, 53], as used in studies of various disease vectors, may help to improve the efficacy and efficiency of vector control program [54-56].

The identified clusters of high house infestation could encompass high risk transmission areas, and should receive special consideration, and possibly more resources, by the vector control program. The relatively high infestation indices recorded in these geographical clusters could be due to various factors such as poverty, economic activities performed to sustain the household (animal husbandry), and local farming habits (special arrangement of peridomestic ecotopes, such as chicken coops and corrals). Low educational level of the population, unawareness of the vector presence risk, the efficacy of the vector control interventions, environmental factors, and potentially the presence of pyrethroidresistant populations could also account for the observed outcome. According to the observations by Porcasi et al. [57], a number of these factors played an important role in the presence and extension of the high infestation clusters in the Argentine Chaco region. Similar factors could be contributing to the persistence and house infestation by $T$. infestans in the studied communities within Toro Toro.

The variables of the Bioclim dataset allowed the characterization of habitats within the environmental hiperspace inhabited by a species [58] and are commonly used to identify, and predict insect distribution areas for individual species [59]. The environmental analysis showed that two alternative models are able to describe the house infestation in the area. The best of the two models explained $57 \%$ of the variation, with four variables: two related to temperature and two to precipitation. The second model explained 53\% of the variation, with only one variable, the minimum temperature of the coldest month, a similar finding to the one reported for the geographic distribution of $T$. infestans in the southern cone of South America [52].

\section{Conclusions}

This study shows the importance of spatial analysis of the persistence of house infestation by $T$. infestans that obliges the maintenance of the vector vigilance and control activities, as well as the identification for the causes of the persistence of this house infestation. The effort to maintain vigilance and control could be efficiently organized following the results reported in this study that helps to spatially stratify the transmission risk over the communities of Toro Toro. This risk stratification could guide the differential assignment of resources by the public health agency of Potosi. 


\section{Additional files}

Additional file 1: Table S1. Number of localities evaluated once or twice a year during the study period. (XLSX $22 \mathrm{~kb}$ )

Additional file 2: Table S2. Number of evaluated houses varied within and between years. (XLS $19 \mathrm{~kb}$ )

Additional file 3: Table S3. Number of evaluated and infested houses according to each of the three methods described above. (XLS $22 \mathrm{~kb}$ )

Additional file 4: Figure S1. House infestation estimated by four alternative methods, based on different assumptions (see text). Blue rectangle: all yearly sample data aggregation, red diamond: highest yearly sample size, yellow triangle: maximum yearly infestation sample, green triangle: first yearly evaluation. (TIF 5074 kb)

Additional file 5: Supporting Information (DOC 32 kb)

\section{Abbreviations}

CC: Community coverage; CE: Number of house evaluations; Cl: Confidence interval; CP: Number of infested houses; EV: Environmental variables; GLM: Generalized linear model; HC: House coverage; HE: House evaluations; HI: House infestation; ID: Intradomestic; NPCCD: National Chagas Programme; ns: Not significant; OR: Odds ratio; PAHO: Pan American Health Organization; PD: Peridomestic; SE: Standard error; SEDES: Health Departmental Service; vif: Variance inflation factor

\section{Acknowledgments}

This study was supported by the Project CNPq/process N 400628/2013-9 Pesquisador Visitante Especial - PVE and PEC-PG Capes/Brazil through granting of a doctoral scholarship (15254-12-7) to Jorge Espinoza Echeverria. We thank the National Chagas Desease of Bolivia and Marinely Bustamante Gomez.

\section{Funding}

Not applicable.

\section{Availability of data and materials}

The data supporting the conclusions of this article are included within the article and its Additional files 1, 2,3,4 and 5 .

\section{Authors' contributions}

All authors have contributed substantially to this study. Conceived the study: JEE, DEG, LGD. Acquisition and compilation of the data: JEE, ANR, MRC. Analyzed and interpreted the data: JEE, DEG. Wrote the paper: JEE, LGD, DEG. All authors read and approved the final manuscript.

\section{Competing interests}

The authors declare that they have no competing interests.

\section{Consent for publication}

Not applicable.

\section{Ethics approval and consent to participate}

Not applicable.

\section{Author details}

'Laboratório de Referência Triatomíneos e Epidemiologia da Doença de Chagas, Centro de Pesquisas René Rachou, FIOCRUZ- MG, Belo Horizonte, Brazil. ${ }^{2}$ Servicio Departamental de Salud - Potosi, Programa Nacional de Chagas, Potosi, Bolivia. ${ }^{3}$ CEADES Salud y Medio Ambiente /Plataforma Chagas, Cochabamba, Bolivia. ${ }^{4}$ Instituto Multidisciplinario de Biología Vegetal (IMBIV-CONICET), Córdoba, Argentina.

Received: 6 August 2016 Accepted: 12 January 2017

Published online: 02 February 2017

\section{References}

1. World Health Organization. Chagas disease in Latin America: an epidemiological update based on 2010 estimates [cited 2015 Jun 2]. http://www.who.int/wer/ 2015/wer9006/en/.

2. Zeledón R. Epidemiology, modes of transmission and reservoir hosts of Chagas' disease. In: Elliot K, O'Connor M, Wolstenholme GF, editors.
Trypanosomiasis and leishmaniasis with special reference to Chagas' disease. Amsterdam: Associated Scientific Publishers; 1974. p. 51-77.

3. Carbajal de la Fuente AL, Yadón ZE. A Scientometric evaluation of the Chagas disease implementation research programme of the PAHO and TDR. PLoS Negl Trop Dis. 2013;7(11):e2445.

4. Lent $\mathrm{H}$, Wygodzinsky P. Revision of the triatominae (Hemiptera, Reduviidae), and their significance as vectors of Chagas' disease. Bull Am Mus Nat Hist. 1979;163:125-520

5. Soto-Vivas A. Clave pictórica de triatóminos (Hemiptera: Triatominae) de Venezuela. Bol Mal Salud Amb. 2009;49(2):259-74.

6. Forattini OP. Biogeografia, origem e distribuição da domiciliação de triatomíneos no Brasil. Rev de Saúde Públ. 1980;14:265-99.

7. Germano M, Picollo M, Spillmann C, Mougabure-Cueto G. Fenitrothion: an alternative insecticide for the control of deltamethrin-resistant populations of Triatoma infestans in northern Argentina. Med Vet Entomol. 2014;28(1):21-5. doi:10.1111/mve.12014

8. Moncayo A. Chagas disease: current epidemiological trends after the interruption of vectorial and transfusional transmission in the Southern Cone countries. Mem Inst Oswaldo Cruz. 2003:98(5):577-91.

9. Cortez MR, Emperaire L, Piccinali RV, Gürtler RE, Torrico F, Jansen AM, Noireau F. Sylvatic Triatoma infestans (Reduviidae, Triatominae) in the Andean valleys of Bolivia. Acta Trop. 2007;102:47-54.

10. Programa Nacional de Control de Chagas (PNCCH). Anuario Programa Nacional de Chagas Bolivia. La Paz: Estado Plurinacional de Bolivia Ministerio de Salud y Deportes Dirección General de Servicios de Salud Unidad de Epidemiologia Programa Nacional de Chagas; 2008.

11. Romaña C. Enfermedad de Chagas. Buenos Aires: López Libreros; 1963.

12. Guillén G, Diaz R, Jemio A, Cassab JA, Pinto CT, Schofield CJ. Chagas disease vector control in Tupiza, Southern Bolivia. Mem Inst Oswaldo Cruz. 1997:92:1-8.

13. Valencia Tellería A. Investigación epidemiológica nacional de la enfermedad de Chagas. In: Investigación Epidemiológica Nacional de la Enfermedad de Chagas. La Paz: Ministerio de Previsión Social y Salud Publica; 1990. p. 184.

14. Jauregui $L$. Aspectos epidemiológicos y clínicos de la enfermedad de Chagas en el Departamento de Santa Cruz. La Paz: La reunión Nacional sobre la enfermedad de Chagas; 1974

15. Ribera B. Aspectos socioeconómicos y culturales de la enfermedad de Chagas. Ann Soc Belg Med Trop. 1985:1-8.

16. Programa Nacional de Control de Chagas-Ministerio de Prevención Social y Salud Pública (PNCCH-MPSSP): Hacia una acción integral y sistémica para el logro de un desarrollo de salud. In. 1991. Ed: Programa Nacional de control de ChagasMinisterio de Prevención Social y Salud Publica República de Bolivia; 1991. p 35.

17. Instituto Nacional de Estadística (INE). Censo de Población y vivienda. 2015. http://www.ine.gob.bo. Accessed 20 Feb 2015.

18. Organización Panamericana de Salud. XVIlla. Reunión de la Comisión Intergubernamental de la Iniciativa Subregional Cono Sur de Eliminación de Triatoma infestans y la Interrupción de la Transmisión Transfusional de la Tripanosomiasis Americana, Cochabamba, Bolivia. 2008. http://www.paho.org/hq/ index.php?option=com_docman\&task=doc_view\&gid=15807\&ltemid=270. Accessed 20 Feb 2014.

19. Schofield CJ, Jannin J, Salvatella R. The future of Chagas disease control. Trends Parasitol. 2006:22(12):583-8.

20. Gürtler RE. Sustainability of vector control strategies in the Gran Chaco Region: current challenges and possible approaches. Mem Inst Oswaldo Cruz. 2009: 104:52-9.

21. Germano MD, Picollo Ml, Mougabure-Cueto GA. Microgeographical study of insecticide resistance in Triatoma infestans from Argentina. Acta Trop. 2013;128(3):561-5.

22. Dias JCP. Southern Cone Initiative for the elimination of domestic populations of Triatoma infestans and the interruption of transfusion Chagas disease: historical aspects, present situation, and perspectives. Mem Inst Oswaldo Cruz. 2007;102:11-8.

23. Cécere MC, Vázquez-Prokopec GM, Ceballos LA, Gurevitz JM, Zárate JE, Zaidenberg $M$, et al. Comparative trial of effectiveness of pyrethroid insecticides against peridomestic populations of Triatoma infestans in northwestern Argentina. J Med Entomol. 2006;43(5):902.

24. Vazquez-Prokopec GM, Cécere MC, Canale DM, Gürtler RE, Kitron U. Spatiotemporal patterns of reinfestation by Triatoma guasayana (Hemiptera: Reduviidae) in a rural community of northwestern Argentina. J Med Entomol. 2005;42(4):571-81.

25. Gurevitz JM, Gaspe MS, Enriquez GF, Provecho YM, Kitron U, Gürtler RE. Intensified surveillance and insecticide-based control of the Chagas disease 
vector Triatoma infestans in the Argentinean Chaco. PLoS Negl Trop Dis. 2013;7(4):e2158.

26. Picollo MI, Vassena C, Santo Orihuela P, Barrios S, Zaidemberg M, Zerba E. High resistance to pyrethroid insecticides associated with ineffective field treatments in Triatoma infestans (Hemiptera: Reduviidae) from Northern Argentina. J Med Entomol. 2005:42(4):637-42.

27. Lardeux F, Depickère S, Duchon S, Chavez T. Insecticide resistance of Triatoma infestans (Hemiptera, Reduviidae) vector of Chagas disease in Bolivia. Trop Med Int Health. 2010;15(9):1037-48.

28. Germano M, Santo-Orihuela P, Roca-Acevedo G, Toloza A, Vassena C, Picollo M, Mougabure-Cueto G. Scientific evidence of three different insecticide-resistant profiles in Triatoma infestans (Hemiptera: Reduviidae) populations from Argentina and Bolivia. J Med Entomol. 2012:49(6):1355-60.

29. Navarro G, Maldonado M. Geografía ecológica de Bolivia: Vegetación y ambientes acuáticos. In: Navarro G, Maldonado M, editores. Centro de Ecología Simón I. Patiño. Cochabamba: Departamento de Difusión; 2002. p. 243-451.

30. Torrico M, Lara R. Parque Nacional Toro Toro: Una guía para su interpretación. La Paz: ACT, Konrad Adenauer, LIDEMA; 2000.

31. USAID-Bolivia. Proyecto integrado de seguridad alimentaria / USAID BOLIVIA. EDH-I-12-05-00005-00. 2011. http://pdf.usaid.gov/pdf_docs/PA00J2T7.pdf. Accessed 25 Feb 2014.

32. Silveira AC, Sanches O. Guía para muestreo en actividades de vigilancia y control vectorial de la enfermedad de Chagas. 2003. http://www.paho.org/uru/ index.php?gid=57\&option=com_docman\&task=doc_view. Accessed Feb 2011.

33. Programa Nacional de Control de Chagas-Escudo Epidemiológico, Ministerio de Salud y Deporte (PNCCH): Manual de Operaciones de Campo. In. 2000. Ed: Programa Nacional de control de Chagas- Ministerio de Salud y Deporte, La Paz-Bolivia; 2000. p. 53.

34. Organización Mundial de la Salud. Enfermedad de Chagas serie de informes técnicos NN202. 1960. http://apps.who.int/iris/bitstream/10665/37634/1/WHO_ TRS_202_spa.pdf. Accessed 12 June 2014.

35. World Health Organization (WHO). Pesticides and their application: for the control of vectors and pests of public health importance. 2006. http://whqlibdoc.who.int/hq/2006/WHO_CDS_NTD_WHOPES_GCDPP_2006. 1_eng.pdf. Accessed 25 June 2015.

36. Team RC. R: A language and environment for statistical computing. Vienna: R Foundation for Statistical Computing; 2013. Document freely available on the internet at: http://www.r-project.org. 2015.

37. Kulldorff M. A spatial scan statistic. Commun Stat Theory Methods. 1997; 26(6):1481-96.

38. Gorla DE, Porcasi X, Hrellac H, Catalá SS. Spatial stratification of house infestation by Triatoma infestans in La Rioja, Argentina. Am J Trop Med Hyg. 2009;80:405-9.

39. Hijmans RJ, Cameron SE, Parra JL, Jones PG, Janvis A. Very high resolution interpolated climate surfaces for global land areas. Int J Climatol. 2005;25:1965-78.

40. Guzmán RJ. Historia de la enfermedad de Chagas. Gac Med Boliviana. 2007;70-73.

41. Arata A, Balderrama F, Bermudez H, Navin T, Ormsby G, Torrico F, Velarde R. Trabajo de la SNS CCH/programa piloto de control de Chagas. La Paz: Ministerio del Desarrollo Humano, Secretaria Nacional de Salud; 1994.

42. Ministerio de Salud y Prevención Social (MSSP), (PNCCH) PNdPyCdledC. Estrategia de información, educación y comunicación del programa de Chagas. 2003.

43. Espinoza N, Borrás R, Abad-Franch F. Chagas disease vector control in a hyperendemic setting: the first 11 years of intervention in Cochabamba, Bolivia. PLoS Negl Trop Dis. 2014;8:e2782.

44. Gorla DE, Ortiz RV, Catalá SS. Control of rural house infestation by Triatoma infestans in the Bolivian Chaco using a microencapsulated insecticide formulation. Parasit Vectors. 2015;8:255.

45. Schofield CJ, Marsden PD. The effect of wall plaster on a domestic population of Triatoma infestans. Bull PAHO. 1982;16(356):60

46. Cécere M, Gürtler R, Chuit R, Cohen J. Factors limiting the domestic density of Triatoma infestans in north-west Argentina: a longitudinal study. Bull WHO. 1998; $76(4): 373$

47. Gürtler RE, Cécere MC, Rubel DN, Schweigmann NJ. Determinants of the domiciliary density of Triatoma infestans, vector of Chagas disease. Med Vet Entomol. 1992;6:75-83.

48. Gurevitz JM, Ceballos LA, Gaspe MS, Alvarado-Otegui JA, Enríquez GF, Kitron U, Gürtler RE. Factors affecting infestation by Triatoma infestans in a rural area of the humid Chaco in Argentina: a multi-model inference approach. PLoS Negl Trop Dis. 2011;5(10):e1349.

49. Gaspe MS, Provecho YM, Cardinal MV, Fernández M, Gürtler RE. Ecological and sociodemographic determinants of house infestation by Triatoma infestans in indigenous communities of the Argentine Chaco. PLoS Negl Trop Dis. 2015;9:e3614

50. Lorenzo MG, Lazzari CR. Temperature and relative humidity affect the selection of shelters by Triatoma infestans, vector of Chagas disease. Acta Trop. 1999;72(3):241-9.

51. Sandoval CM, Cárdenas R, Morales AJR, Jaimes E, Mendoza JG. Medio ambiente y protozoosis sistemicas III. Los vectores de la enfermedad de Chagas y su asociación con los factores climáticos. Academia. 2006;5(9):65-74.

52. Gorla DE. Variables ambientales registradas por sensores remotos como indicadores de la distribución geográfica de Triatoma infestans (Heteroptera: Reduviidae). Ecol Austral. 2002;12:117-27.

53. Reisen WK. Landscape epidemiology of vector-borne diseases. Annu Rev Entomol. 2010;55:461-83.

54. Ruiz MO, Tedesco C, McTighe TJ, Austin C, Kitron U. Environmental and social determinants of human risk during a West Nile virus outbreak in the greater Chicago area, 2002. Int J Health Geogr. 2004;3:8.

55. Diuk-Wasser MA, Brown HE, Andreadis TG, Fish D. Modeling the spatial distribution of mosquito vectors for West Nile virus in Connecticut, USA. Vector-Borne Zoon Dis. 2006;6:283-95.

56. Palaniyandi M, Anand P, Maniyosai R. Spatial cognition: a geospatial analysis of vector borne disease transmission and the environment, using remote sensing and GIS. Information Systems. Inter J Mosq Res. 2014;1(3):39-54.

57. Porcasi X, Catalá SS, Hrellac H, Scavuzzo MC, Gorla DE. Infestation of rural houses by Triatoma infestans (Hemiptera: Reduviidae) in southern area of Gran Chaco in Argentina. J Med Entomol. 2006;43(5):1060-7.

58. Flith $\mathrm{JH}$, Graham C, Anderson RJ, Dudík M, Ferrier S, Guisan A, et al. Novel methods improve prediction of species' distributions from occurrence data. Ecography. 2006;29:129-51.

59. Booth TH, Nix HA, Busby JR, Hutchinson MF. BIOCLIM: the first species distribution modelling package, its early applications and relevance to most current MAXENT studies. Divers Distrib. 2014;20:1-9.

\section{Submit your next manuscript to BioMed Central and we will help you at every step:}

- We accept pre-submission inquiries

- Our selector tool helps you to find the most relevant journal

- We provide round the clock customer support

- Convenient online submission

- Thorough peer review

- Inclusion in PubMed and all major indexing services

- Maximum visibility for your research

Submit your manuscript at www.biomedcentral.com/submit
( Biomed Central 